\title{
Um momento decisivo na história RAYMUNDO FAORO
}

$\mathrm{O}$ $S$ DOCUMENTOS QUE MUDARAM o mundo, abrindo novas épocas ou revelando nacionalidades, nos tempos modernos têm um singular acento comum. O Contrato Social (1762), A Declaração de Independência (1776), Que é - Terceiro Estado (1789) e O Manifesto Comunista vivem, ainda hoje, além do significado de sua mensagem política pela energia literária que os moldou. A combinação entre política e literatura não é nova, bastando lembrar um Burke e um Joseph de Maistre, sem mencionar Disraeli e Chateaubriand. Esses homens, vinculados à tradiçáo do exercício da política, educados pela filosofia e pelas letras - a alta política das idéias e das causas - não ultrapassaram o seu tempo e a sua época. Os outros, acima mencionados, ainda que esgotada sua causa e mudadas as circunstâncias, entraram no patrimônio perene da política. É claro que não foram as qualidades literárias que lhe deram o realce e a permanência. Mas, pode-se dizer que, despidos do pathos que os inspirou e foi insculpido na compulsiva força estilística, permaneceriam como duram os monumentos mortos.

Há, no conjunto das obras citadas, duas espécies: obras dedicadas primeiramente à ciência ou à filosofia política, mas que, eventualmente, alcançam efeitos políticos, que não o propósito principal. É o caso do Contrato Social, que no máximo faria parte, com excepcional relevo, da chamada cultura militante. (Si j'etais prince ou législateur, je ne perdrais pas mon temps à dire ce qu'il faut faire; je le ferais, ou je me tairais.), mas não imediatamente atuante. Ao contrário, a Declaração de Independência, a obra de Sieyès, bem como O Manifesto Comunista participam da ação política, ainda que, em muitos respeitos, o último verse, proféticamente, de uma realidade não atual, mas in fieri, que viria a se formar 50 anos depois. $O$ Contrato Social produziria as linhas básicas de Que é o Terceiro Estado, realizando-se em grande parte, na Declaração dos Direitos do Homem e do Cidadão de 1789, na vanguarda, além disso, das idéias dos homens que Tocqueville chamou de hommes de lettres, um conjunto de escritores que, pela primeira vez na história, teriam formado a mentalidade de um século, o XVIII francês. 
A veemência estilística, com o toque da mais pura arte, nos melhores momentos da arte literária, legou, nas obras que fizeram história, está ainda gravada na memória dos contemporâneos. Quem não lembrará o capítulo I do livro I de $O$ Contrato Social:

"L'homme est né libre, et partout il est dans les fers. Tel se croit le maître des autres, qui ne laisse pas d'être plus esclave qui'eux.

\section{A Declaração da Independência:}

"We hold these truths to be self evident, that all men are created equal; that among these are life, liberty and the pursuit of happiness."

O exemplar maior da arte literária ao serviço da política está, superando seus precedentes, no Manifesto Comunista. Combina a grandeza da profecia bíblica com a imaginação literária. Nele ressoam, subjacentes à palavra explícita, metáforas, imagens e temas da literatura universal (S.S. Prawer - Karl Marx and World Literature, 1978; Steven Marcus - Marx's Masterpiece at 150, NYT, 26.4.98; Eric Hobsbawnm - The Communist Manifesto, 1998). Já se observou que o Manifesto Comunista é um palimpsesto (imagem que usou no texto, ao observar que os socialistas alemães importaram o socialismo, como um palimpsesto ao revés), debaixo de cujas palavras lê-se a voz dos poetas alemães, às vezes com um acento original. Exemplo disso, entre os muitos que se podem escolher, o poema de Goethe - $O$ Aprendiz de Feiticeiro - em que o aprendiz, na evocação, se transmuta no próprio feiticeiro: a moderna burguesia é como o feiticeiro que náo pode mais controlar seus poderes, no mundo que ela criou com sua mágica (a citação não é integral). Em pelo menos duas passagens é visível, para o leitor experimentado, o eco de Heine, poeta de sua especial admiração.

Um dos momentos mais inspirados da literatura política universal, com o ritmo dual das palavras que se fazem ação, será o primeiro parágrafo do $\mathrm{Ma}$ nifesto:

"Um espectro ronda a Europa: o espectro do comunismo. Todas as potências da velha Europa se uniram numa santa aliança para exorcizar esse espectro: o Papa e o Czar, Metternich e Guizot, radicais franceses e espióes policiais alemães."

A parte final fecha epicamente essa obra singular e única, como que ecoando os passos da revolução comunista, que nunca se realizou: "Os proletários nada tem a perder, senão seus grilhóes." Há imagens inesperadas, com um enérgico poder de concretizar o pensamento abstrato, fundado na dialética, 
exposta pela via da arte, como, por exemplo: a burguesia gerou seus coveiros. Interminável seria a mostra desse quadro, de nenhuma maneira secundário, como se demonstraria se maior o espaço disponível.

Raymundo Faoro é jurista, sociólogo, historiador e cientista político. Lançou, em 1958, a primeira ediçáa de $O s$ donos do poder. Foi o primeiro professor-visitante do IEA-USP, durante o segundo semestre de 1986. 